\title{
Un processo integrato di conoscenza e visualizzazione. Il castello della Reggia di Portici
}

\author{
Lia Maria Papa \\ Pierpaolo D'Agostino
}

\section{Abstract}

II contributo vuole descrivere le premesse metodologiche e le fasi operative di un processo per la creazione di un sistema di informazioni integrato e interattivo, finalizzato alla disseminazione e fruizione del patrimonio culturale. La sempre crescente necessità di provedere a sistemi che permettano di fornire una base di conoscenza di manufatti e contesti che per loro natura o per fatti contingenti non sono disponibili all'interazione, sta sempre più beneficiando dell'attuale progresso tecnologico per quel che concerne da un lato lo sviluppo di piattaforme software atte alla creazione di sistemi di conoscenza interattivi, dall'altro l'accesso agevole a spazi digitali web-based che rappresentano un luogo virtuale ove è possibile confrontarsi con un variegato apparato informativo di varia natura e formato.

L'esigenza di definire una metodologia di sistema e nel contempo di testare l'efficacia ed efficienza di vari strumenti operativi, ha animato quindi la ricerca presentata [I], calatasi in un contesto di particolare complessità storica e spaziale: la Reggia di Portici.

Parole chiave

Cultural Heritage, Siti Reali, processi integrati, GIS, Virtual modeling.

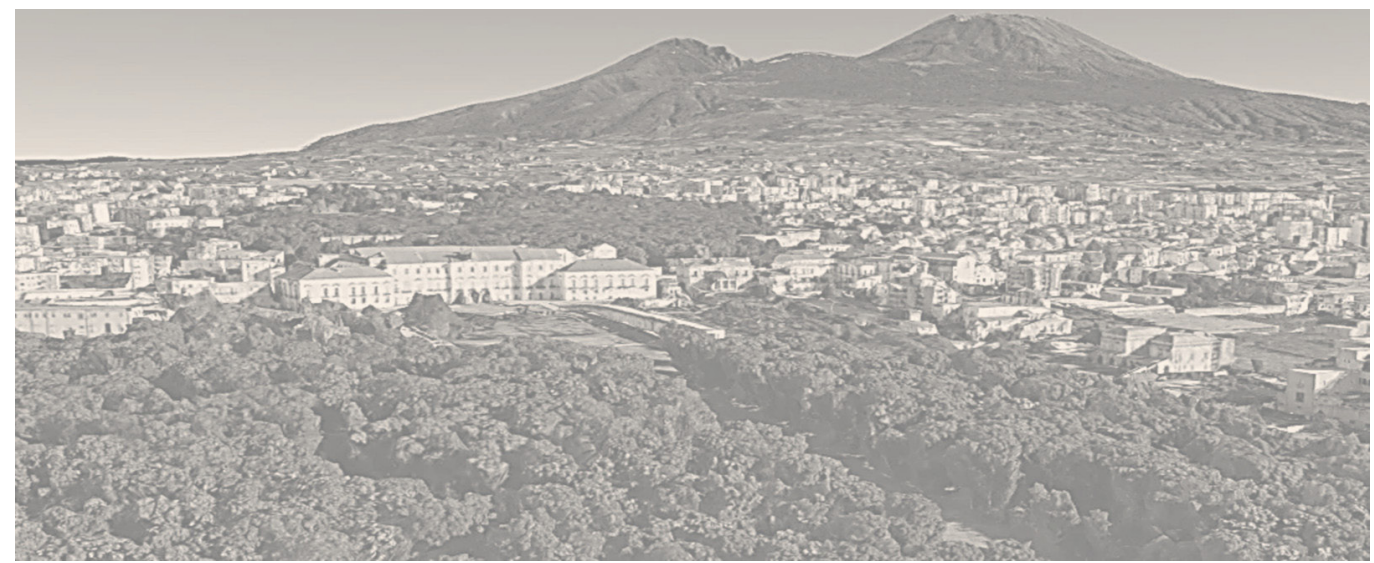




\section{Introduzione}

“Oggi non ci può essere un passaggio unidirezionale delle informazioni e dei saperi [...]. La vera riflessione generazionale sta nel saper collaborare, nel voler stabilire un lavoro di rete, condividere informazioni, tener conto di linguaggi diversi" [Fatta 2019, p. I6] [2]. Queste parole esprimono un aspetto fondamentale del modo contemporaneo che sempre più si sta consolidando e del messaggio, anche etico, relativo alla crescente responsabilità degli attori coinvolti nel processo di gestione delle informazioni. Ciò comporta anche dare giusto peso alle tecnologie digitali ed al loro contributo, in particolare nel campo dei beni culturali e nella visualizzazione digitale di numerose architetture o contesti di pregio storico.

Strumenti digitali che trovano la loro spinta propulsiva in termini di loro diffusione nella creazione di strumenti nati per il gaming che manifestano evidenti caratteristiche di flessibilità operativa quando riescono ad essere piegati alla necessaria richiesta di rigore metodologico, in particolare se applicate alla ricerca operativa di settore sfruttando un approccio che contempli l'uso sapiente di processi per una gestione informativa integrata. (L.M.P.).
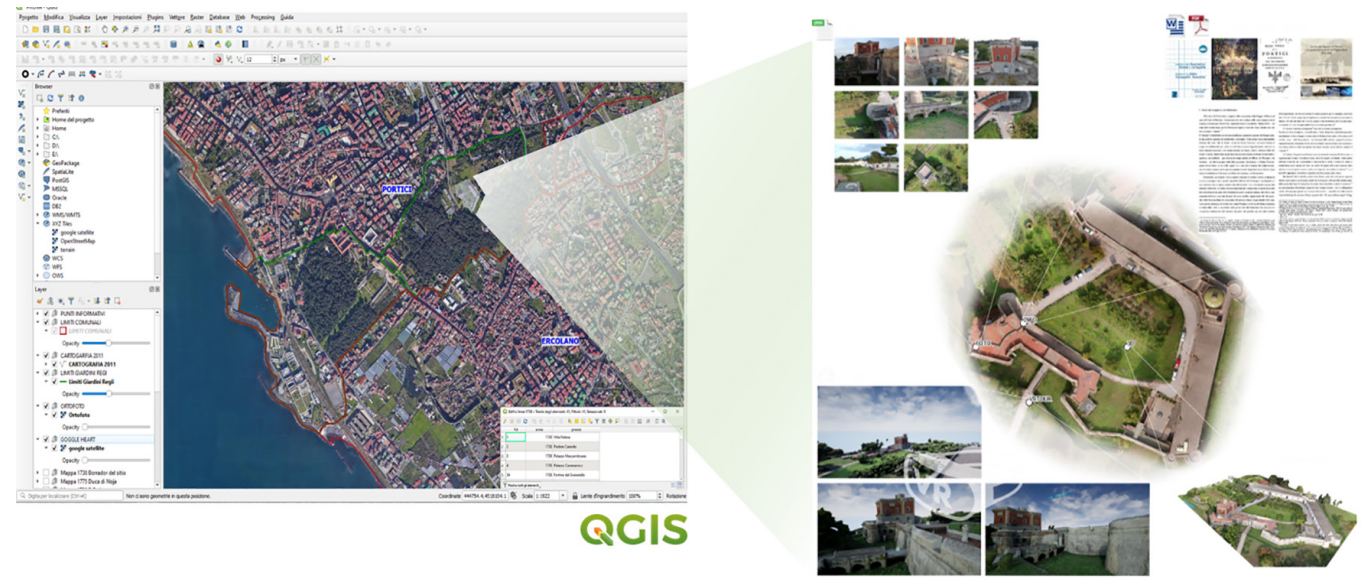

\section{La Reggia di Portici: un microcosmo urbano}

Nel giro di appena quindici anni - dal 1738 al 1753 - furono avviati nell'attuale territorio della Campania i lavori per la realizzazione di tre grandi residenze reali: Capodimonte, Portici e Caserta. Di queste la Reggia di Portici è la meno nota, o meglio è nota agli studenti universitari, essendo il Palazzo Reale sede del Dipartimento di Agraria dell'ateneo federiciano, è nota agli abitanti del Comune di Portici, i quali possono fruire di una porzione del parco - quella prossima al mare - che è racchiusa, come tutto il complesso, nel tessuto urbano, è noto, infine, gli studiosi delle antichità storiche di Ercolano e Pompei, essendo stata la Reggia sede dell'Museo Ercolanense.

Diverse e parziali percezioni e fruizioni, dunque, di un luogo che, da quando è stato edificato, ha avuto momenti di abbandono e un lento recupero, tutt'ora in corso [3].

E' innegabile che le caratteristiche paesaggistiche del sito hanno giocato un ruolo fondamentale, in un'area prossima al mere, da sempre caratterizzata dalla presenza attiva del Vesuvio. Il vulcano ed il mare hanno condizionato infatti l'impianto complessivo della residenza reale, situata a cavallo dell'antica Strada Regia delle Calabrie, e protesa sia verso il Vulcano che verso il mare, con un chiaro riferimento prospettico.

Come confermato da molti storici dell'architettura, il pregio del sito reale non è tanto architettonico, quanto paesaggistico e ambientale [Nocerino 1787].

L'intero progetto nacque per aggregazioni e progetti successivi, opera di vari architetti e ingegneri [4]; ciò complesso documentare visivamente l'evoluzione dei luoghi [Papa 2019]. 
I lavori esecutivi, iniziati nel 1738, furono conclusi sotto Ferdinando IV di Borbone che, salito al trono di Napoli e Sicilia ancora bambino, nel I775, fece costruire nella zona più lontana dal mare, le attrazioni che si andavano diffondendo all'epoca nelle corti europee, come "il muro per il gioco della palla", oltre ad un castello per consentire lo svolgimento di esercitazioni militari [5] [Del Pezzo I896]. (L.M.P.).
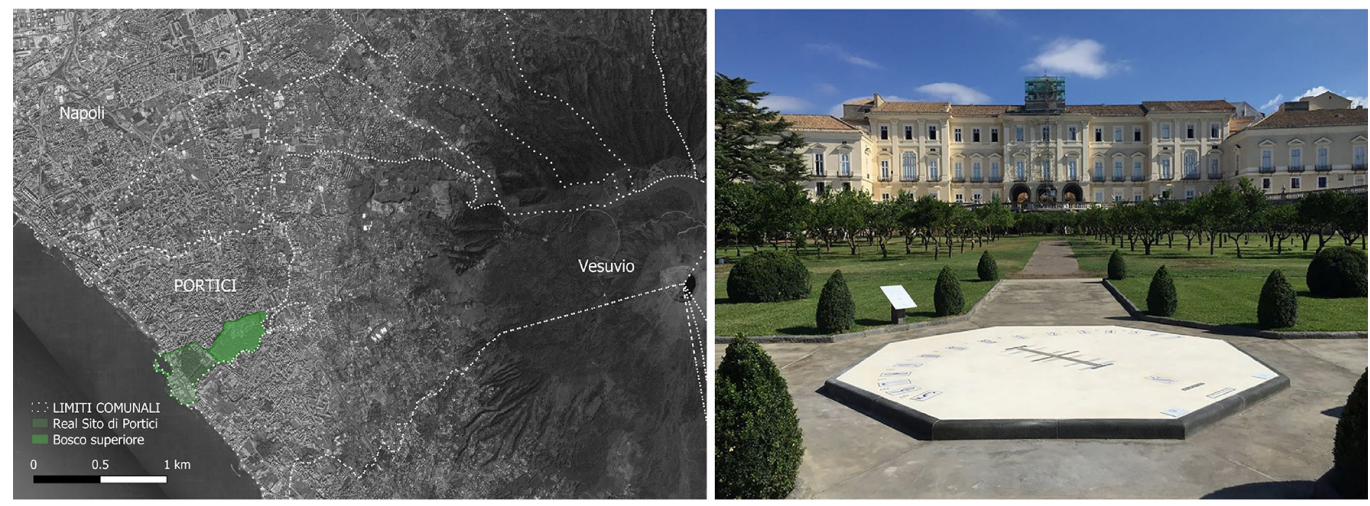

\section{Un'applicazione di gestione integrata}

La conclamata possibilità per cui si possa immaginare l'applicazione di strumenti a navigazione libera di scenari e contesti reali, induce ad interrogarsi sulla opportunità di sfruttare i relativi contenuti digitali alla stregua di modelli informativi per una fruizione, ampia e immateriale, di contesti reali. Ciò è come dire che, se l'interazione del contesto digitalizzato da parte di un'utenza non esperta tenderebbe a giustificare, in una piena accezione di gaming [Smith 2019], che si possa interagire con forme dal limitato aumento informativo, questo diviene meno accettabile quando l'interpretazione sintetica richieda che si eviti ambiguità, ossia quando al dato si dà accesso ad un'utenza esperta, interessata a fruire di dati per applicazioni di natura tecnica oltre che meramente ricreativa.

La necessità di integrare e distribuire informazioni per una base informativa e conoscitiva aggregata, quando legata alla conoscenza di oggetti che si collocano in più ampi sistemi complessi [Centofanti 2008], conduce ad una informazione grafica attraverso un processo di resa tanto alla scala territoriale od urbana quanto a quella di dettaglio. In tal senso, quindi, quando si intende distribuire l'informazione multiscalare, la costruzione di sistemi informativi web-based ad hoc definiti diviene il mezzo più adeguato per l'articolazione proprio di un database relazionale che, nella pianificata organizzazione di modelli e elaborati informativi, bidimensionali e tridimensionali, si possa configurare come link tra adeguata rappresentazione tematica e modelli solidi fruibili interattivamente, tendenti ad una dimensione scalare prossima a quella reale [D'Agostino, Messina 20I8].

Queste considerazioni hanno indotto al verificare, attraverso il caso campione rappresentato dal Real Sito di Portici e nello specifico del complesso del Castello e del Fortino presenti nel parco superiore dell'area di studio, entro quali margini si sia in grado di predisporre per l'appunto un coerente database relazionale di tipo GIS il cui contenuto informativo possa essere fruibile attraverso una piattaforma ad hoc sviluppata, incentivando il legame interattivo tra mera componente grafica e informativa in senso più ampio attraverso un motore grafico open-source. Nella fattispecie, dunque, l'attenzione rivolta al metodo operativo ha inteso condizionare lo sviluppo operativo, cercando in tal senso di piegare uno specifico assetto software alle finalità definite.

Per poter procedere alla costruzione di un sistema informativo utile tanto all'organizzazione ed alla gestione quanto alla fruizione e alla disseminazione del materiale repertato, il processo di metodo messo in piedi ha previsto la suddivisione del lavoro in quattro focus, 
Fig. 3. F. Geri e L. Malesci, "Pianta generale del Sito in cui si contengono il Palazzo Reale di Portici e giardini e boschetti dipendenti", seconda metà del XVIII sec., Napoli, Biblioteca Naziona ( Binistra teca Nazionale (a sinistra) e Oficio topografico, Piante topografiche de Reall Delizie di Portici, Nazionale (a destra). rappresentati dall'approfondire la conoscenza del sito in oggetto, favorire la gestione del bene tanto finalizzata alla manutenibilità del bene quanto per il suo godimento ricettivo e, a ciò legato, valutare e costruire gli strumenti più opportuni per una sua valorizzazione totale. I focus sono stati concepiti in parallelo, ma hanno poi trovato attuazione in una sequenza implementativa che ha riguardato in primis un momento di riflessione circa la definizione del quadro esigenziale. Un tale quadro ha preso le mosse dal necessario aggiornamento e dalla relativa organizzazione dell'apparato grafico tecnico, atto a completare ed integrare i materiali in possesso alle strutture di gestione. Puntando quindi alla messa in relazione dei dati geografici legati alle features nel database, l'approccio seguito ha preso le mosse dal riferire il patrimonio cartografico raster - sia parlando di materiali topograficamente coerenti che di acquisizioni relative a rappresentazioni prescientifiche - con la cartografia tecnica vettoriale e georeferenziata del comune di Portici [Chías, Papa 2019].
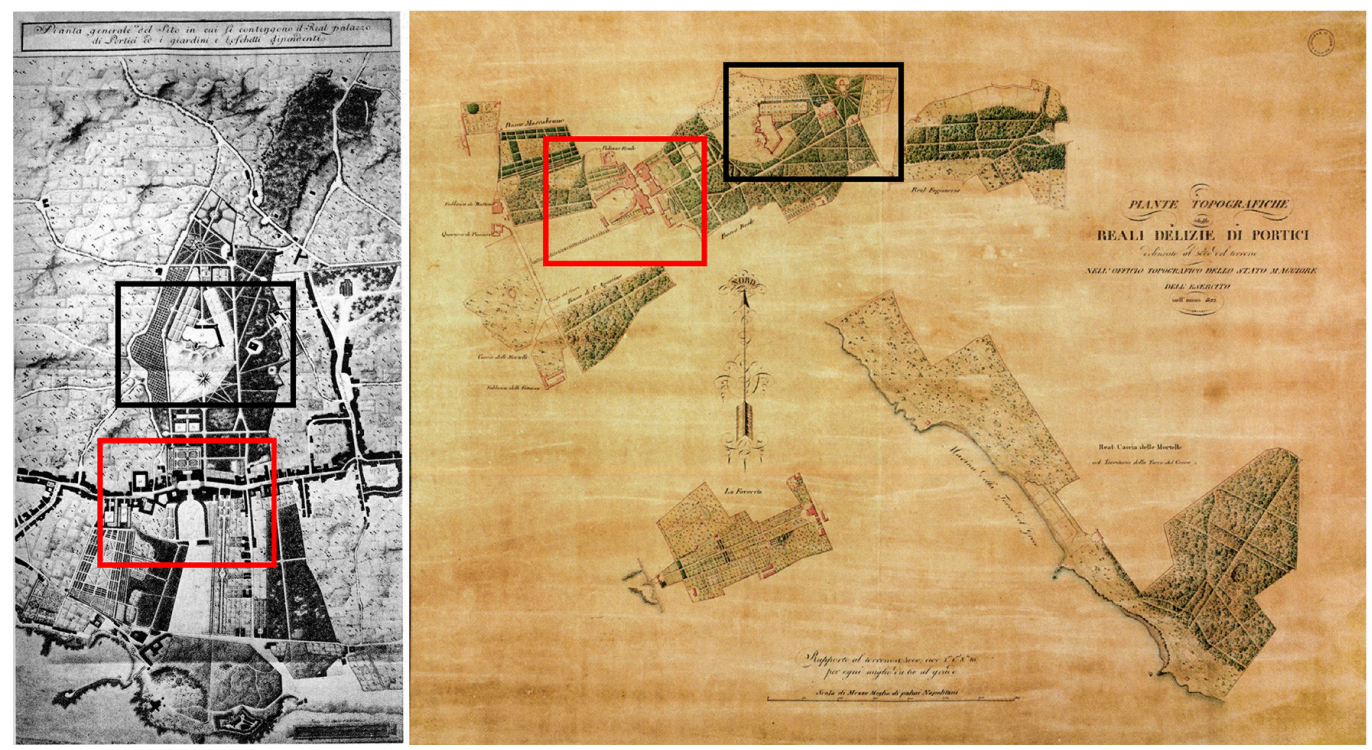

Attraverso un processo di rubber-sheeting si è raggiunto lo scopo di riferire dati storicizzati ad un sistema di riferimento corrente, adeguato quindi ad analisi comparative in particolare del sistema organizzativo ed evolutivo delle aree verdi, modificatesi nel tempo per la nascita dei manufatti presenti nel Parco - il Castello è tra questi il caso più rilevante - e per la differente destinazione d'uso del suolo dei diversi comparti territoriali tagliati dagli assi viari. Inoltre, I'analisi diacronica del materiale sistematizzato ha confermato la cardinalità di alcune strutture invarianti nel sistema edificato, tra le quali il complesso in parola è risultato essere il più emblematico e suscettibile di approfondimento specifico.

Accettata l'esigenza dell'aggiornamento grafico del contesto oggetto di analisi, allo scopo di produrre modelli il più possibile univoci, è stata pianificata e condotta una campagna di rilevamento SAM per fotogrammetria aerea. Date le condizioni non formalmente critiche, di un sito aperto, non ricadente in no fly zone ma prossimo ad un contesto insediativo congestionato, si è proceduto alla pianificazione di voli automatici con mezzo a vista, impedendo il volo oltre la quota operativa di 20 metri, immediatamente al di sopra del manufatto in parola, che ha definito la necessità di processamento di sei voli, adeguati a coprire i circa 2 ettari su cui insiste il sistema costruttivo oggetto di studio, in particolare prevedendo 4 voli per coprire l'area di circa nella sua totalità, con una sovrapposizione tra essi di circa 60\%, ed altri 2 voli di dettaglio per il solo castello. Attraverso l'acquisizione totale di circa 1600 prese aeree, il rilevamento ha prodotto un DTM con un Ground Sampling Distance di 7,8 $\mathrm{mm}$ per pixel, garantendo quindi un modello superficiale utile a generare di viste e sezioni ortografiche per la produzione grafica di elaborati in scala l: 100. 
Posta l'efficacia del database che si configura in definitiva come collettore informativo sia di elaborati che di documenti informativi, un punto cruciale della sperimentazione ha riguardato le modalità attraverso le quali produrre e implementare la modellazione tridimensionale nel sistema informativo e di come la stessa riesca a configurarsi come base digitale interattiva. Per procedere alla organizzazione infografica che ha condotto ad immaginare il ricorso a rappresentazioni digitali più dettagliate, simulando in forma paradigmatica il passaggio di scala da quella urbana a quella edilizia ed architettonica, il processo immaginato ha integrato nel sistema informativo una modellazione atta interattivamente ad un sistema multipiattaforma per il tramite di formati markup language di tipo descrittivo, creando allo scopo apposite applicazioni web-based linkate dal webGIS precedentemente definito.

Fig. 4. A sinistra: Pianta generale dei fabbricati e dei terreni della Regía Scuola di Agricoltura di Portici. Napoli, 1906. A destra: veduta del Castello e del suo ingresso confrontato con l'omologo del Castello d Capua (in basso).
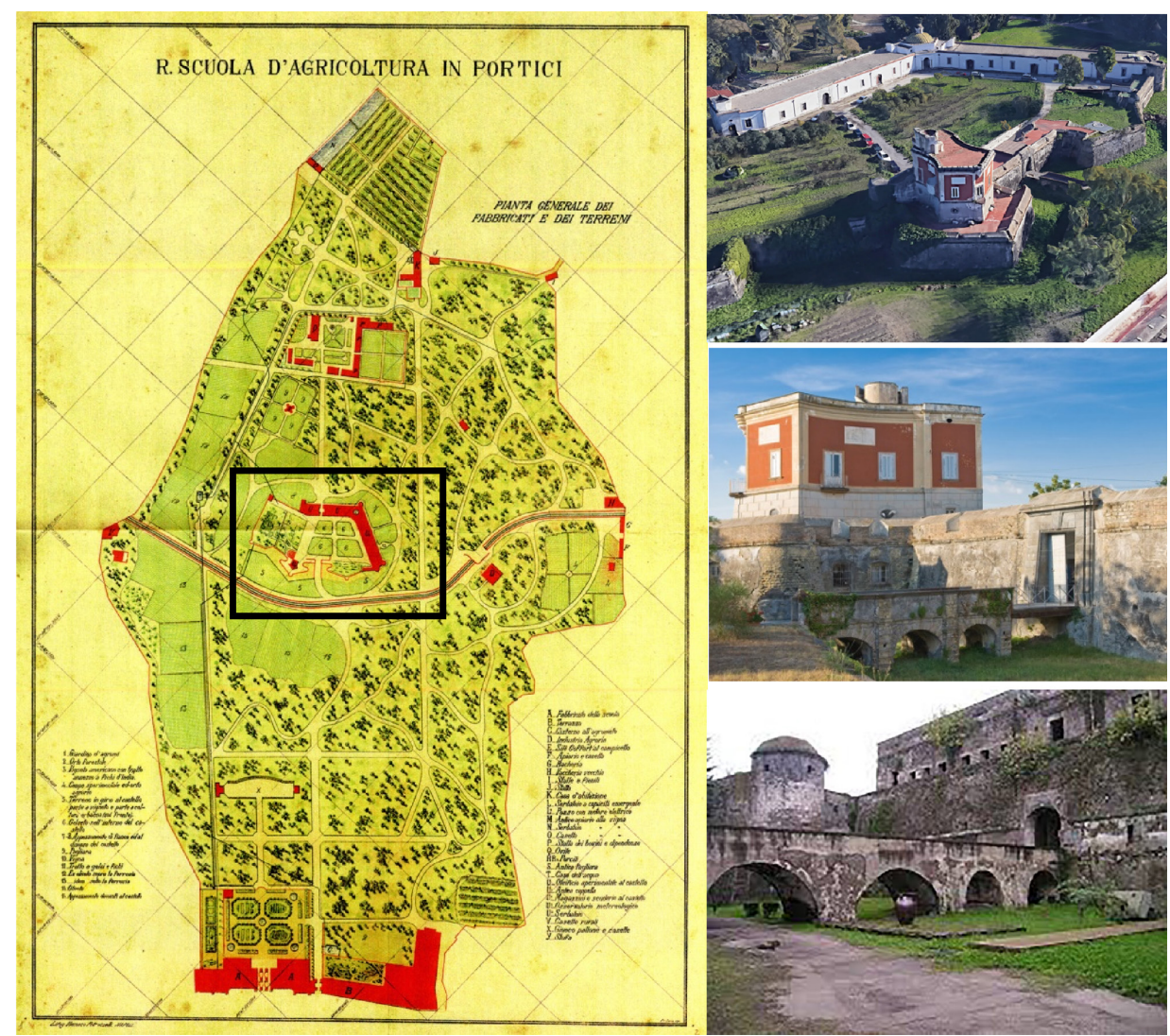

Tale modello è apparso sin dalle prime battute inutilizzabile all'interno del software GIS selezionato, che in quanto tale prevede il ricorso ad una rappresentazione solida di tipo mesh e, di contro, manifesta l'impossibilità ad integrare oggetti solidi strutturati. Questo limite diviene invero un'opportunità alla luce della volontà di interazione tra i due momenti interattivi: il sistema informativo in quanto tale e l'integrato modello virtuale all'atto della migrazione verso l'applicazione in virtual reality (VR).

Peraltro, il modello mesh consente l'auspicata coerenza geometrica del manufatto, potendo ottenerla attraverso il medesimo processo di acquisizione per fotogrammetria aerea che ha permesso di redigere l'aggiornamento cartografico introdotto e descritto in precedenza. Ciò è come dire che tanto il modello implementato nella piattaforma GIS quanto in Unreal Engine - motore grafico utilizzato per questa applicazione - si configura come una riproduzione digitale attendibile del Castello e del fortino al suo contorno con una risoluzione ampiamente adeguata a simulare l'oggetto nella navigazione nell'accessibilità ricettiva virtuale e, per l'interazione con un'utenza esperta, richiamare puntualmente le informazioni rigorose degli elaborati prodotti. (G.DA.). 
Fig. 5. Articolazione e sequenza operativa
dalla fotomodellazion dalla fotomodellazione all'aggiornamento grafico
tecnico e al modello immersivo.

Fig. 6. Selezione delle caratteristiche tecniche e del GSD per i piani divolo.

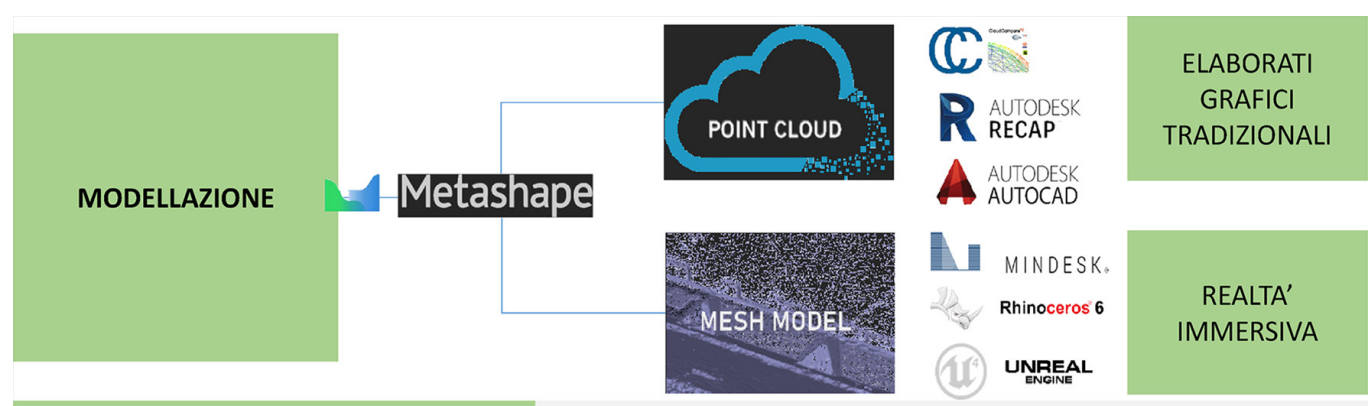

ELABORATI GRAFICI TRADIZIONAU

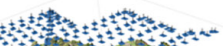

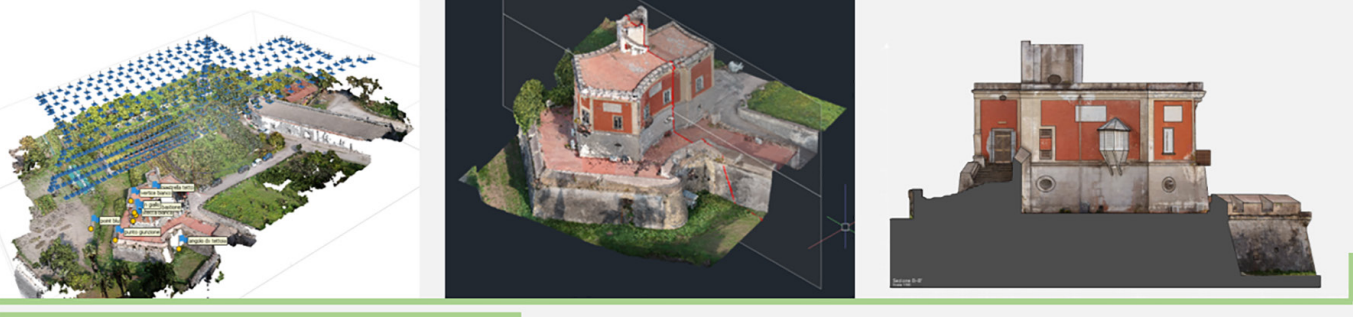

REALTA' IMMERSIVA

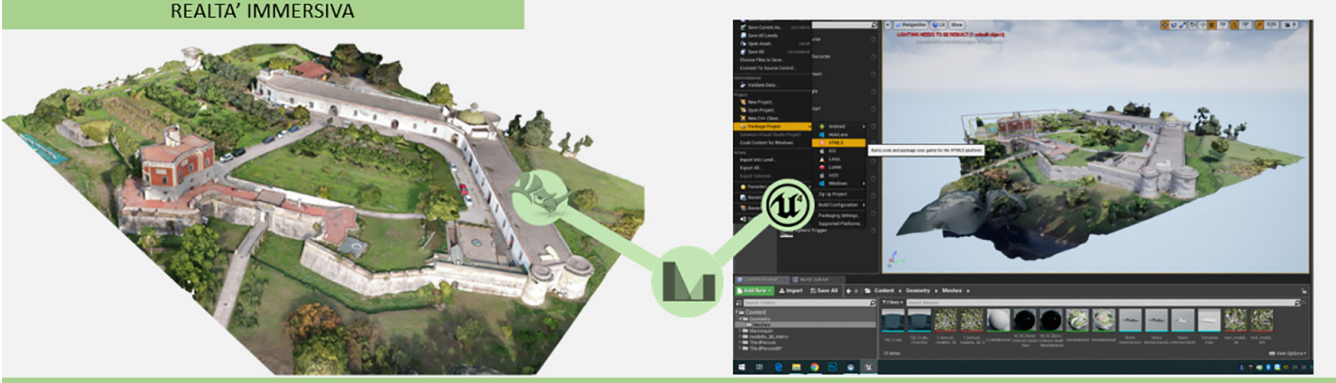

\begin{tabular}{l} 
SENSORE FOTOGRAFICO \\
\hline LAREHEZZA
\end{tabular}

\begin{tabular}{|c|c|}
\hline & \\
\hline nuluserst & menturersi \\
\hline
\end{tabular}
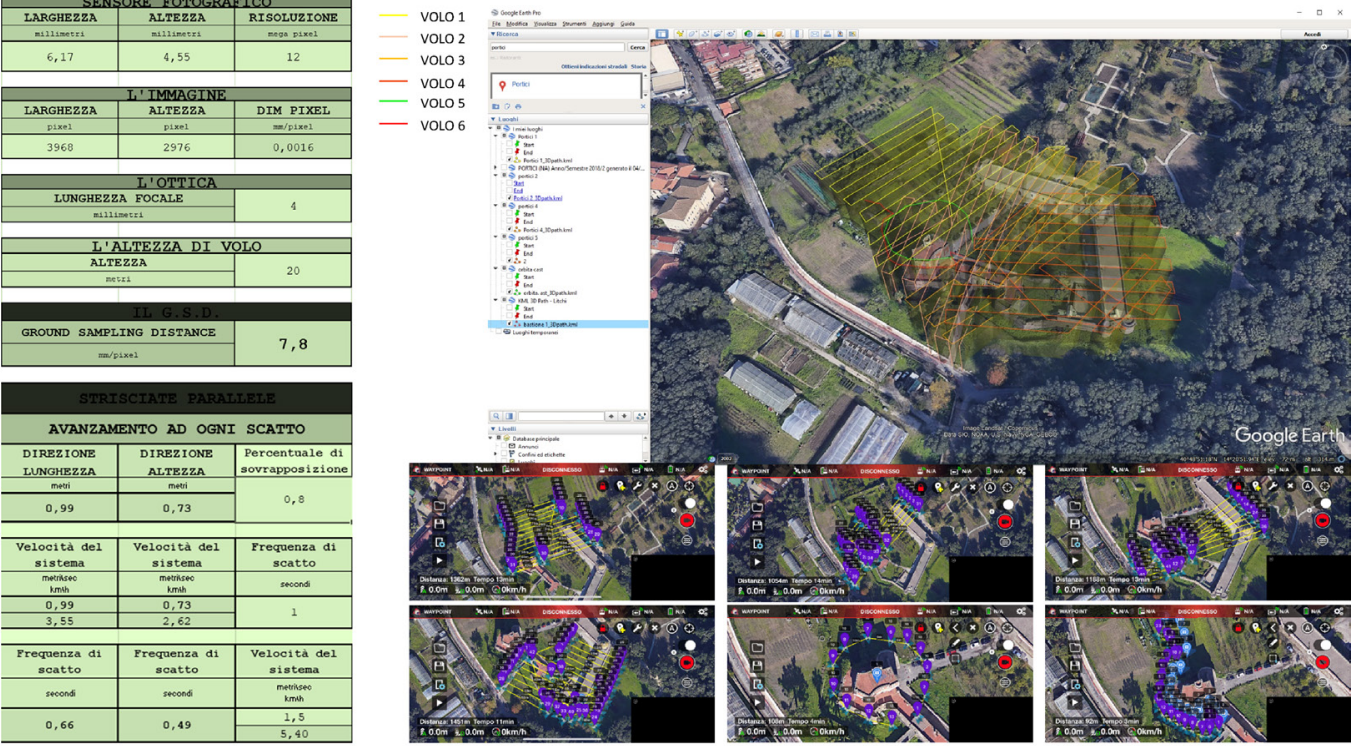
Fig. 7. Selezione degli

l'aggiornamento grafico

laggiornamento grafico

metrico.

Fig. 8. L'implementazione del modello nel motore grafico: gestione delle

entità geometriche per l'output immerisivo.
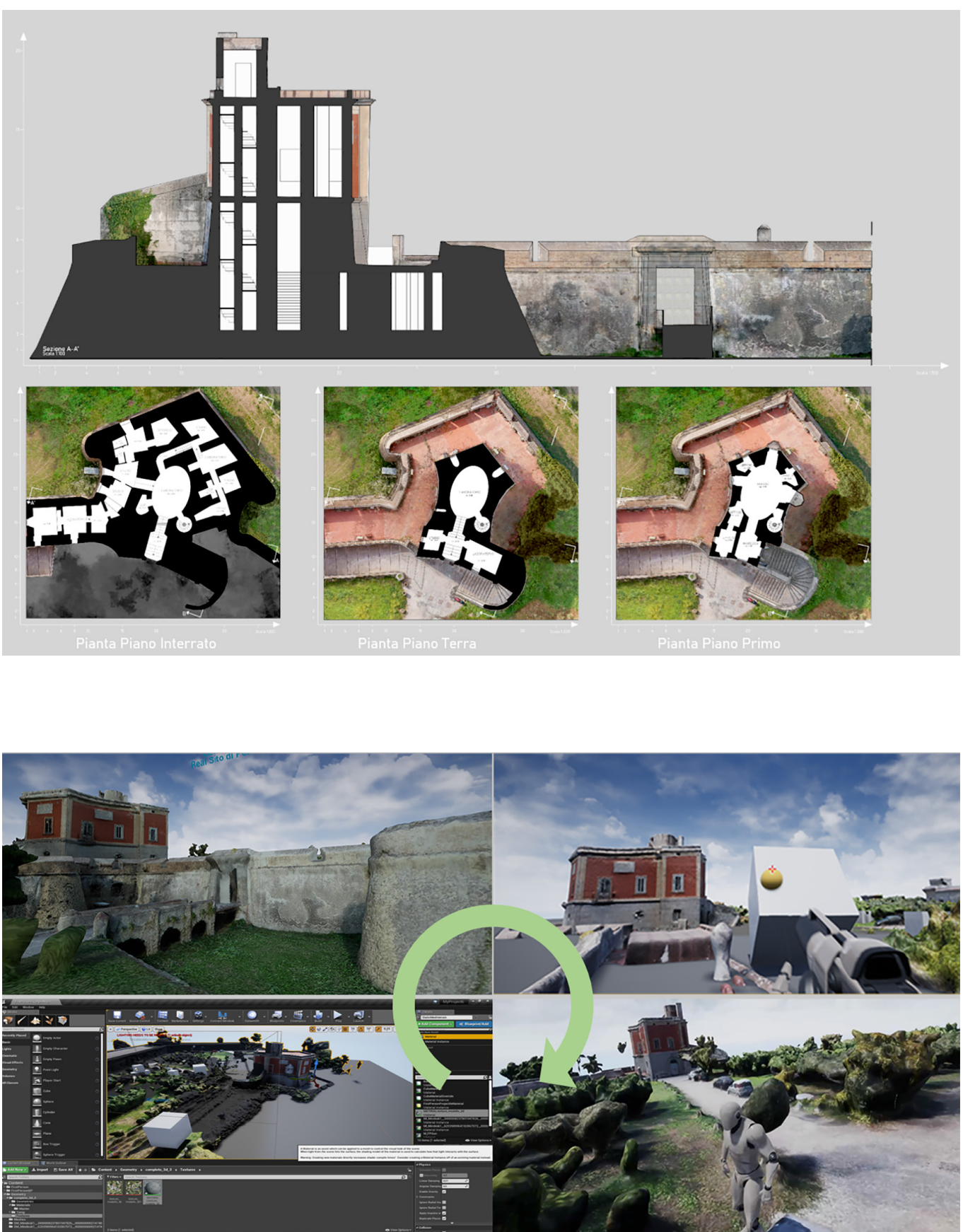


\section{Conclusioni}

Se è facile considerare che esiste da oltre mezzo secolo il consueto a confrontarsi con scenari immaginifici prodotti all'interno di piattaforme atte a creare mondi interattivi ideali per mera finalità ricreativa e ludica, meno immediato è il tema del ricorso alla modellazione e alla digitalizzazione di contesti reali che si manifestino nelle loro condizioni metriche ed informative coerenti all'interno di simili procedure.

La necessità di integrare informazioni relazionate ad una univoca base informativa, se legata alla conoscenza di oggetti che si collocano in più ampi sistemi complessi, manifesta l'esigenza di produrre le informazioni grafiche attraverso un processo di rappresentazione e visualizzazione, tanto alla scala territoriale od urbana quanto a quella di dettaglio

Nel caso specifico, lo sviluppo di strumenti di modellazione avanzata e la loro interconnessione con motori grafici multipiattaforma messi a disposizione di un'utenza ampia e variegata, ha concesso anche alla comunità scientifica di testare modalità inedite di organizzazione informativa. Questa organizzazione viene vista come un viatico in grado di abbattere la distanza tra il momento della collezione del dato e la sua condivisione. (L.M.P.).
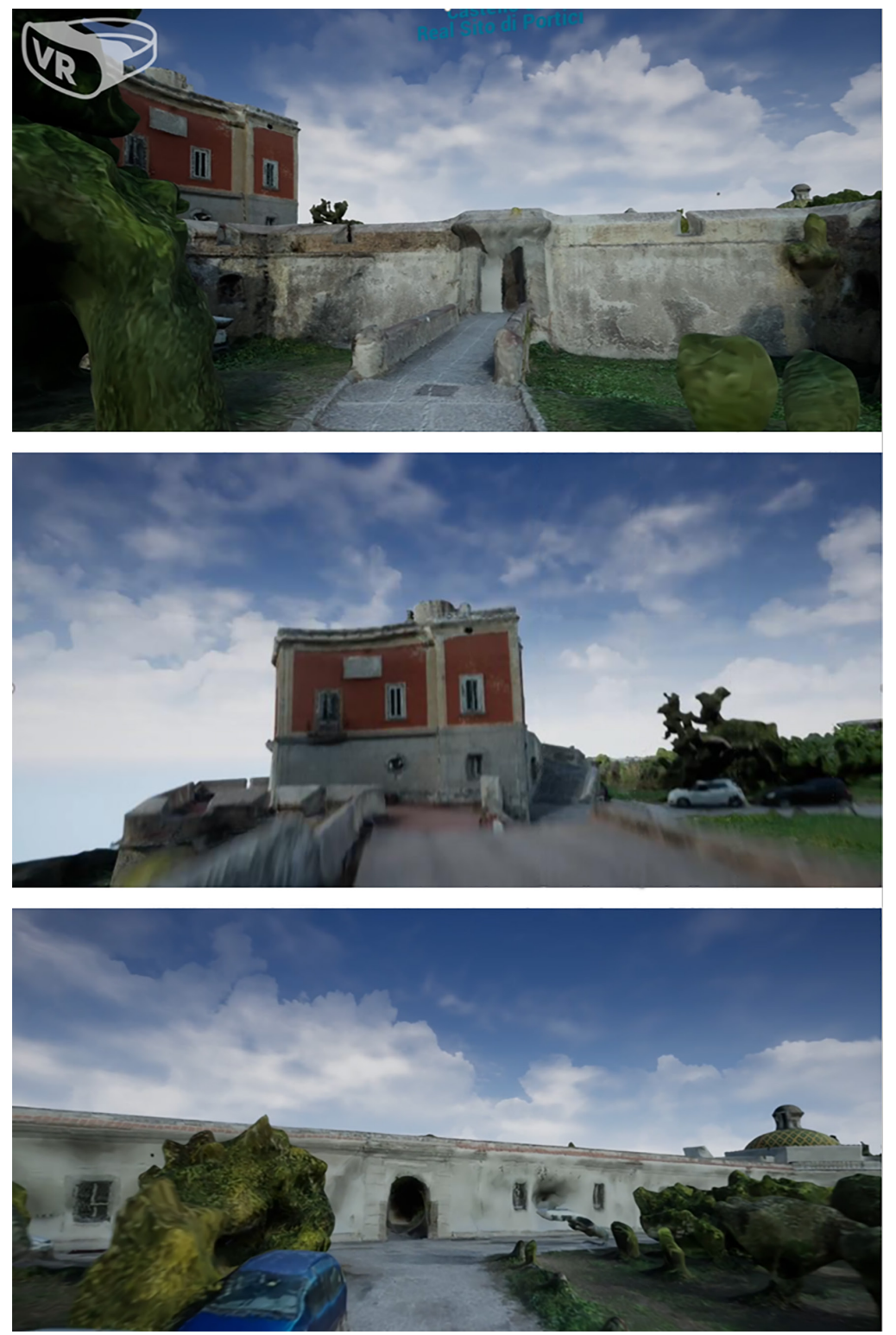


\section{Note}

[I] II lavoro presentato è da intendersi curato nella sua interezza dai due autori in particolare per il coordinamento delle attività di ricerca qui esposta in una sintesi preliminare, fermo restando il contributo individuale per l'articolato in paragrafi come riportato nel testo.

[2] Fatta Francesca (2019). Introduzione. In: Belardi 2019, p. 16.

[3] || Palazzo Reale, con parchi e dipendenze, fu messo in vendita nel | 87| ed acquistato dalla Provincia di Napoli che vi insediò la Scuola Superiore di Agricoltura e, nel 1873, l'Orto Botanico, riservandogli le aree del Parco Superiore. Attualmente la proprietà di questa porzione è dell'Università di Napoli Federico II, con il cui Ufficio Tecnico gli autori collaborano da vari anni.

Un necessario confronto è stato avviato con la Soprintendenza Archelogica, Belle Arti e Paesaggio per l'Area Metropolitana di Napoli, nella figura dell'architetto Serena Borea, funzionario di zona alla Tutela Architettonica dell'Ente. La corrispondenza tra Università ed Ente di tutela, peraltro, è intervenuta alla luce dell'attenzione su un bene ritenuto paradigmatico per gli scopi della Task Force MASBC (Metodologie Analitiche Per La Salvaguardia Dei Beni Culturali) promossa dall'Ateneo di Napoli Federico II, di cui gli autori sono, rispettivamente, membro del comitato di gestione e componente.

[4] Hanno contribuito alla realizzazione principalmente Giovanni Antonio Medrano, Antonio Carnevari, Luigi Vanvitelli.

[5] Progettato dall'ingegnere militare Michele Aprea, sotto la direzione del generale Francesco Pignatelli, esso si ispira al castello di Capua.

\section{Riferimenti bibliografici}

Centofanti Mario, Continenza Romolo, Ruggieri Gianfranco, Brusaporci Stefano, Trizio Ilaria (2008). II progetto del SIARCH - UNIVAQ, Sistema Informativo Architettonico. In: Mingucci Roberto, Centofanti Mario (ed.) Conservazione del Patrimonio Architettonico e Urbano. DisegnareCon, vol. I, n. 2.

Chías Navarro Pilar, Papa Lia Maria (2019). Territories, places and landscapes with figures. In: Chías Navarro Pilar, Papa Lia M. (a cura di). Drawing the territory and the landscape. DisegnareCon, vol. I 2, n.22, pp. I - 10.

D'Agostino Pierpaolo, Messina Barbara (2018). Digital Information Archives for an Integrated Documentation of Eremitical Settlements on Amalfi Coast. In: Marcos Carlos L. (ed.). Graphic Imprints. The Influence of Representation and Ideation Tools in Architecture. Cham: Springer International Publishing, pp. 88I-893.

Del Pezzo Nicola ( 1 896). Siti Reali: il Palazzo Reale di Portici. In: Napoli Nobilissima, V, pp. I6 I - |67, I 83- 88.

Fatta Francesca (2019). Prefazione. In: Belardi Paolo (a cura di). (2019). Riflessioni: l'arte del disegno/ il disegno dell'arte. Atti del $41^{\circ}$ Convegno Internazionale dei Docenti delle Discipline della Rappresentazione. Perugia 19-21 settempre 2019. Roma: Gangemi, p.16-18.

Nocerino Nicola ( 1787). La real villa di Portici. Napoli: Fratelli Raimondi, pp. 46-53.

Papa Lia Maria (2019). Considerations about Old Maps in the Digital Era. In: The Representation of Landscape, Environment and Territory. Diségno n. 5, pp. 91-102.

Smith Matthew, Walford Nigel Stephen, Jimenez-Bescos Carlos. (2019). Using 3D modelling and game engine technologies for interactive exploration of cultural heritage: An evaluation of four game engines in relation to roman archaeological heritage. In Digital Applications in archaeology and Cultural Heritage, 14, 2019, pp. I- I3.

\section{Autori}

Lia Maria Papa, Università degli Studi di Napoli “Federico II", Impapa@unina.it

Pierpaolo D’Agostino, Università degli Studi di Napoli "Federico Il", pierpaolo.dagostino@unina.it

Per citare questo capitolo: Papa Lia Maria, D'Agostino Pierpaolo (2020). Un processo integrato di conoscenza e visualizzazione. II castello della Reggia di Portici/An integrated process for dissemination and visualization. The Castle in the Royal Site in Portici. In Arena A., Arena M., Brandolino R.G., Colistra D., Ginex G., Mediati D., Nucifora S., Raffa P. (a cura di). Connettere. Un disegno per annodare e tessere. Atti del $42^{\circ}$ Convegno Internazionale dei Docenti delle Discipline della Rappresentazione/Connecting. Drawing for weaving relationships. Proceedings of the 42th International Conference of Representation Disciplines Teachers. Milano: FrancoAngeli, pp. 25I5-2532. 


\title{
An Integrated Process for Dissemination and Visualization. The Castle in the Royal Site in Portici
}

\author{
Lia Maria Papa \\ Pierpaolo D'Agostino
}

\section{Abstract}

IThe paper aims to describe the methodological premises and the operational phases of a process for the development of an integrated and interactive informative system, intended for the dissemination and fruition of cultural heritage. The often noticeable need to develop systems that allow to provide a knowledge base to artefacts and contexts that are not available for interaction due to their nature or to contingent circumstances, is increasingly benefiting from the current technological progress with regards, on the one hand, to the development of software platforms aimed at creating interactive knowledge systems, on the other, to the easy accessing to web-based digital spaces which represent a virtual place where it is possible to deal with a wide-ranging informative apparatus. The necessity to define a system methodology and, at the same time, to test the effectiveness and efficiency of several operational tools, animated the current research [I], which fits in a context of specific historical and spatial complexity: the Royal Palace of Portici.

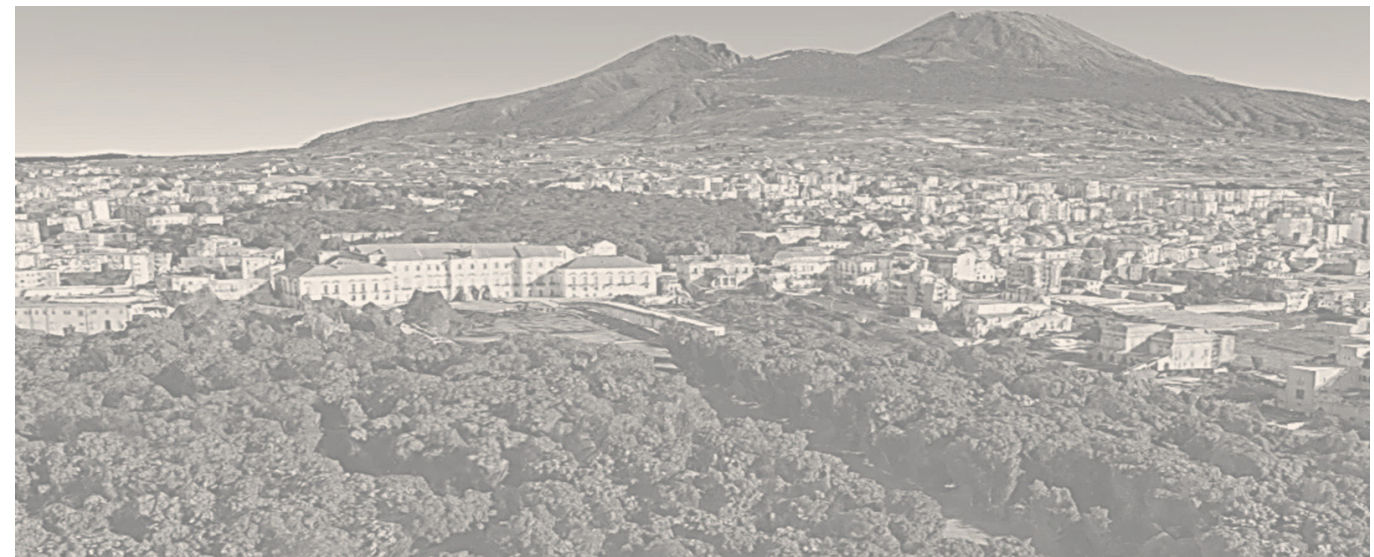


Fig. I. Schematization of the information system about management and use of the Real Sito in Portici.

\section{Introduction}

"Nowadays a one-way flow of information and knowledge cannot be feasible [...] The actual generational thought lies in knowing how to collaborate, share information, take into account different languages, in wanting to establish a network effort"' [Fatta 2019, p. 16] [2]. These words express a fundamental aspect of the contemporary habit that is increasingly consolidating and of the message, also ethical, related to the growing responsibility of the actors involved in the information management process.

This also implies giving due weight to digital technologies and their contribution, in particular in the cultural heritage field and in the digital visualization of many architectures or contexts of historical worth.

Digital tools that find their propulsive thrust in terms of their diffusion in the development of tools born for the gaming purpose, that show noticeable characteristics of operational flexibility when they are suitable to be bent to the overriding requirement of methodological rigor, in particular if applied to sectorial operational research by exploiting an approach that contemplates the wise use of processes for an integrated informative management. (L.M.P.).
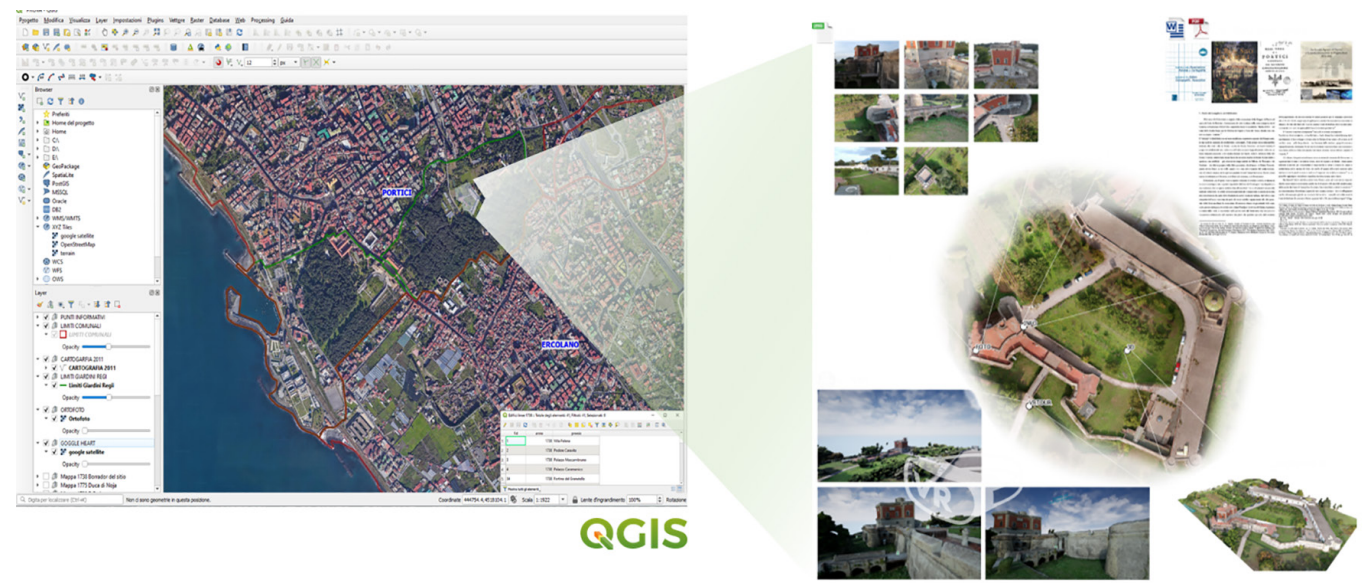

Within just fifteen years -from 1738 to 1753- in the current Campania region began the construction of three large royal residences: Capodimonte, Portici and Caserta.

Of these, the Royal Palace of Portici is the least known, or rather it is known to university students, being the Royal Palace seat of the Agrarian Department of the Federico II university, it is known to the inhabitants of the Municipality of Portici, who can enjoy a portion of the park - the one next to the sea - which is encysted, like the whole complex, in the urban fabric, it is known to the scholars of the historical antiquities of Herculaneum and Pompeii, having been the Palace seat of the Herculaneum Museum.

Different and partial perceptions, therefore, of a place that, since it was built, has had moments of abandonment and a slow recovery, still in progress [3].

It is undeniable that the landscape features of the place played a fundamental role, in an area close to the sea, always characterized by the active presence of Vesuvius.

The presence of the Volcano and the sea conditioned indeed the overall layout of the royal residence located astride the ancient Strada Regia delle Calabrie, and outstretched both towards the Volcano and towards the sea, with a clear perspective reference [Nocerino 1787]. The whole project was born by subsequent aggregations and plans, the work of various architects and engineers [4], which make it hard to visually document the evolution of the spaces. As confirmed by many architectural historians, the Site is not so much valuable under architectural perspective, as under landscape and environmental viewpoint [Papa 2019]. 
The construction, which began in 1738, was completed under the reign of Ferdinando IV of Bourbon who, having ascended the throne of Naples and Sicily while still a child, in I775, built in the upper forest the attractions that were spreading at the time in European courts, such as "the wall for the ball game", as well as a castle to allow military exercises [5] [Del Pezzo 1896].

Designed by the military engineer Michele Andrea under the leadership of General Francesco Pignatelli, it is inspired by the Capua castle. (L.M.P.).
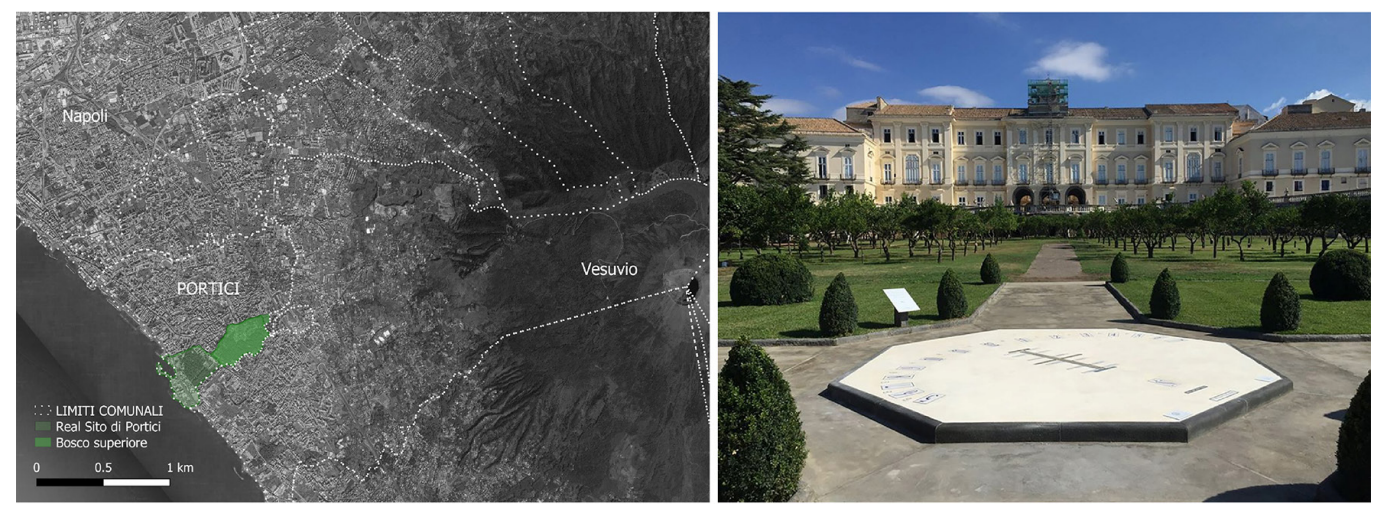

\section{An integrated management application}

The self-evident possibility to imagine the application of free navigation tools of real scenarios and contexts leads to wonder about the opportunity to employ the related digital contents as information systems for a wide and immaterial fruition of real contexts. This is like saying that if the interaction with the digitized context by an inexperienced user would tend to justify, in a full sense of gaming [Smith 2019], that it is possible to interact with forms with a limited information increase, this becomes less acceptable when the synthetic interpretation requires the ambiguity to be avoided. This scenario takes place when the access to the data is given to expert users interested in using data for applications of technical other than merely recreational nature.

The need to integrate and distribute data related to a unique information and knowledge base, if linked to the knowledge of objects that are located in larger complex systems, manifests the need to produce graphic information through a process of rendering both at the territorial or urban scale and at the detailed scale. In this sense, therefore, when it is intended to distribute multi-scalar information, the construction of defined ad hoc web-based information systems becomes the most appropriate means for the articulation of a relational database which, in the planned organization of two-dimensional and three-dimensional models and information documents, can be configured as a link between a satisfactory thematic representation and solid models, tending to a scalar dimension close to the real one, that can be fruited interactively [D'Agostino, Messina 20 I8].

Through the sample case represented by the Real Site of Portici and specifically by the complex of the Castle and Fort in the upper park of the study area, these reflections led to the verification of margins within which it is possible to set up a coherent GIS relational database whose information content can be used through an ad hoc developed platform, promoting the interactive link between the mere graphic and the informative component in a broader sense through an open-source graphic engine.

In the present case, therefore, the attention paid to the operating method was intended to affect the operational development, in this sense trying to bend a specific software structure to the predefined purposes. 
The goal exposed in this paper is, therefore, the formulation of a proposal for an integrated knowledge design by the means of a multi-scalar modelling approach.

In order to proceed with the construction of an informative system useful both for the planning and the management as well as for the fruition and the dissemination of the survey output, the method process put in place involved the partition of the work into four focuses. The focuses are represented by the deepening of knowledge of the site concerned, by the support to the management of the asset both aimed at the asset maintainability as well as at its receptive enjoyment and, linked to this, at the evaluation and the development of the most appropriate tools for its global enhancement.

Fig. 3. F. Geri e L. Malesci, "Pianta generale del Sito in cui si contengono il Palazzo Reale di Portic e i giardini e boschetti dipendenti", 2nd half of XVIII sec., Napoli, Biblioteca Nazionale (on the left ca Nazionale (on the left) and Oficio topografico, Reations ro22. Napoli, Biblioteca Nazionale (on the right).
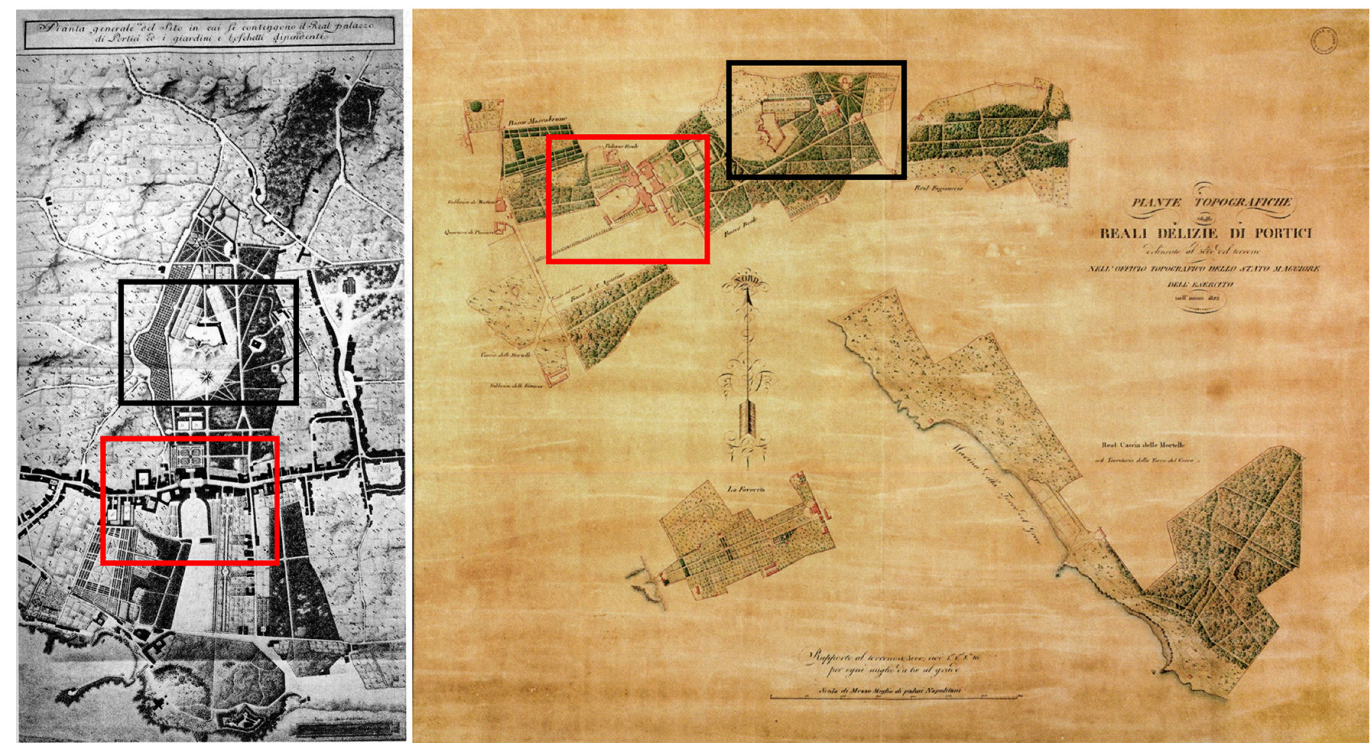

The focuses are conceived in parallel, but then they are implemented in an execution sequence which primarily concerned a moment of reflection regarding the definition of the requirement picture. The findings in this regard showed an atypical condition for a valuable context such as the Real Site of Portici, that was the subject of historical and historiographic investigations of great scientific depth. Such a complex architectural asset manifested a challenging condition of updating and organization of the graphical and technical apparatus, aimed to complete and integrate the materials already possessed by the administration structures.

Therefore, aiming to reconnect the geographical data related to the features in the database, the implemented approach has taken the move from the referencing of the raster cartographic heritage -consisting of both topographically coherent materials and acquisitions related to pre-scientific representations- with vectorial and georeferenced technical cartography and of the Municipality of Portici [Chías, Papa 2019].

The aim of reporting historical data to a current reference system was reached by the means of a rubber-sheeting process. The current system is indeed suitable for comparative analyses, in particular of the organizational and evolutionary system of the green areas, which changed over time because of the emergence of the buildings existing in the Park - the Castle is among these the most relevant case - and for the different destination of land use of the various territorial sectors crossed by the road axes. In addition, the diachronic analysis of the systematized material confirmed the cardinality of some invariant structures in the built system, among which the complex concerned was found to be the most emblematic and capable to be the subject of a specific study. 
Recognized the need for the graphic updating of the analysed context, in order to produce the most univocal models attainable, useful for the desired multiscale use, although reliable and rigorous in metric-formal terms, a SfM survey campaign was planned and conducted by aerial photogrammetry. Given the formally non-critical conditions, of an open site, not falling into a no-fly zone but close to a congested settlement context, automatic flights with the vehicle at sight were planned, preventing the flight beyond the operating altitude of 20 meters, immediately above the building under assessment. The building's features defined the need for processing six flights, adequate to cover the approximately 2 hectares on which the construction system under study is located. Specifically, 4 flights were performed to cover the area approximately in its entirety, with an overlap between them of about $60 \%$, and 2 more detailed flights were conducted for the castle itself. Through a total acquisition of about 1600 aerial shoots, the survey produced a DTM with a Ground Sampling Distance of $7.8 \mathrm{~mm}$ per pixel, thus guaranteeing a surface model useful for generating views and orthographic sections for the graphic production of graphic works in 1: 00 graphic scale.

Fig. 4. On the left: general plan of buindings and land of the Regia Scuola di Agricoltura di Portici. Napoli, 1906. On the right: a view of the Castle its entrance compared with the one of the Capua Castle (below).
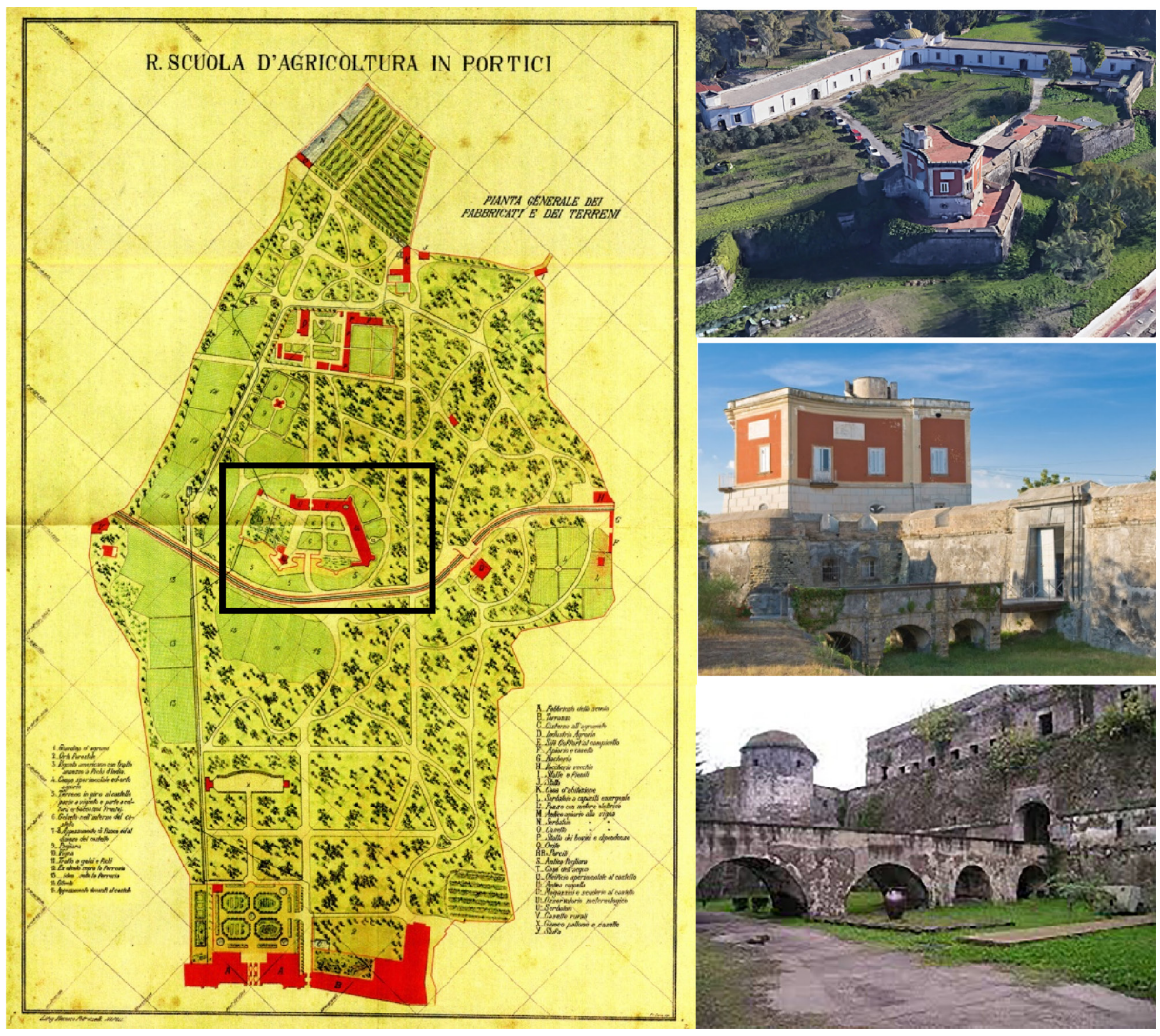

Given the effectiveness of the database which is ultimately configured as an information collector of both documentation and informative files, a crucial point of the experimentation concerned the ways in which to produce and implement the three-dimensional modelling in the informative system and how the model itself can constitute as an interactive digital base. In order to proceed to the infographic organization, that led to envisage the use of more detailed digital representations, simulating in a paradigmatic way the transition from urban to building and architectural scale, the proposed process tended to integrate into the information system a modelling strategy interactively suitable to a cross-platform system through descriptive 'mark-up language' formats, creating for this purpose dedicated web-based applications linked to the previously defined webGIS. This model appeared, from the very beginning, unsuitable for the implementation within the selected GIS software, which 
Fig. 5. Articulation and operational sequence from photo modeling to technical graphical update and immersive model.

Fig. 6. Selection of technical characteristics and GSD for flight plans.

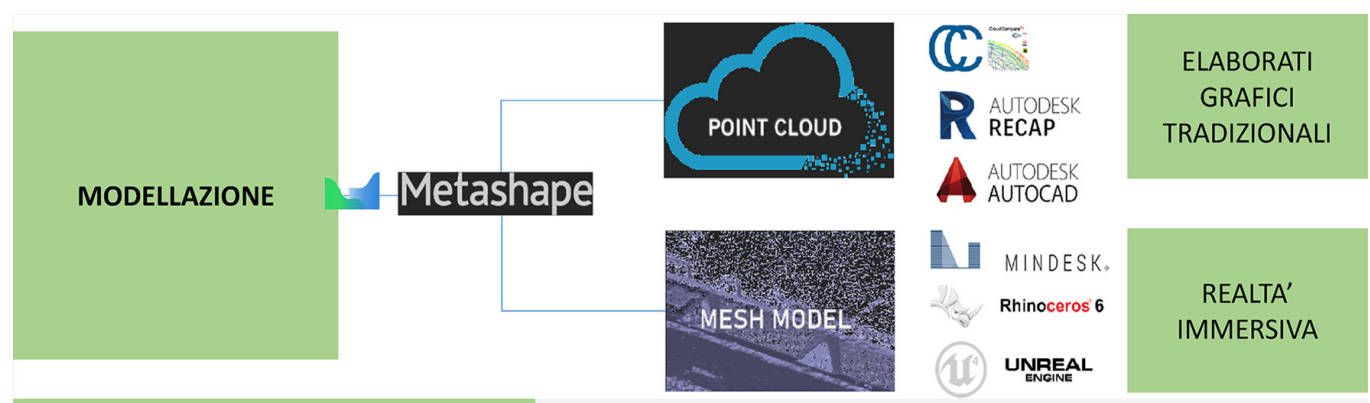

ELABORATI GRAFICI TRADIZIONALI

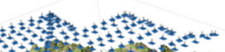
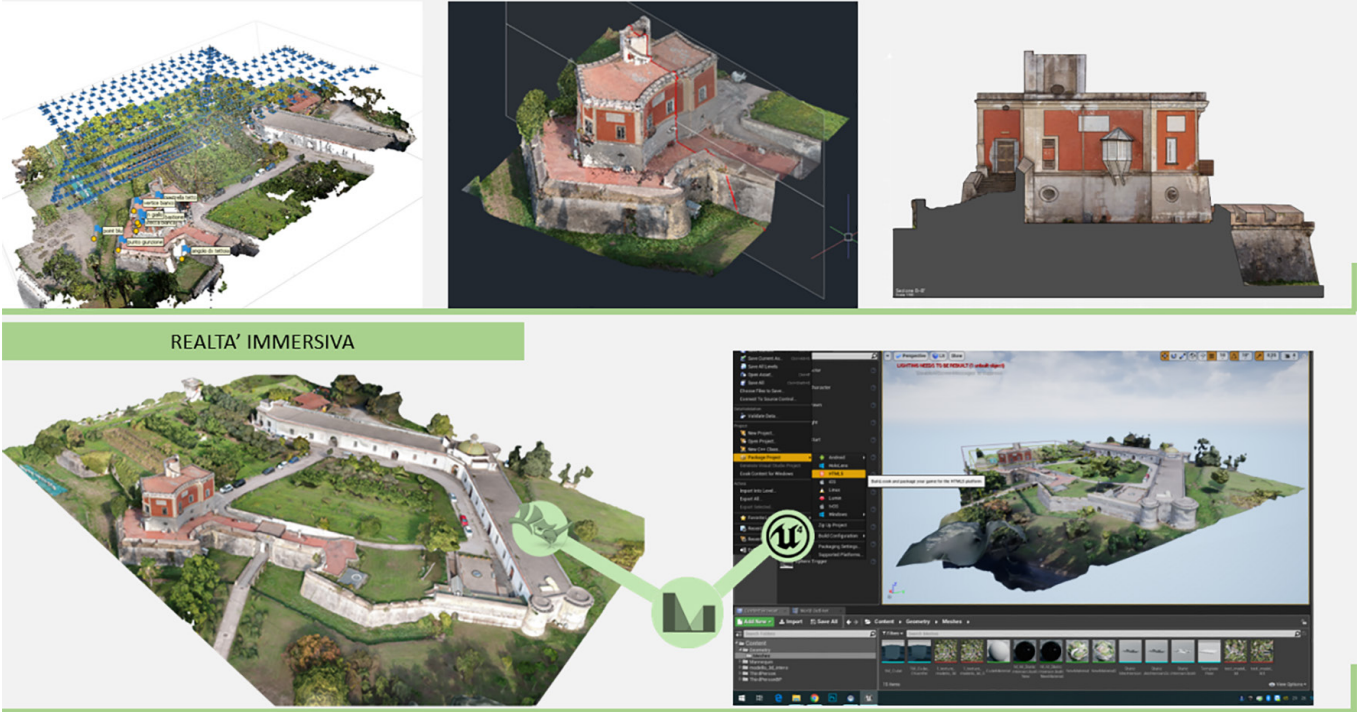

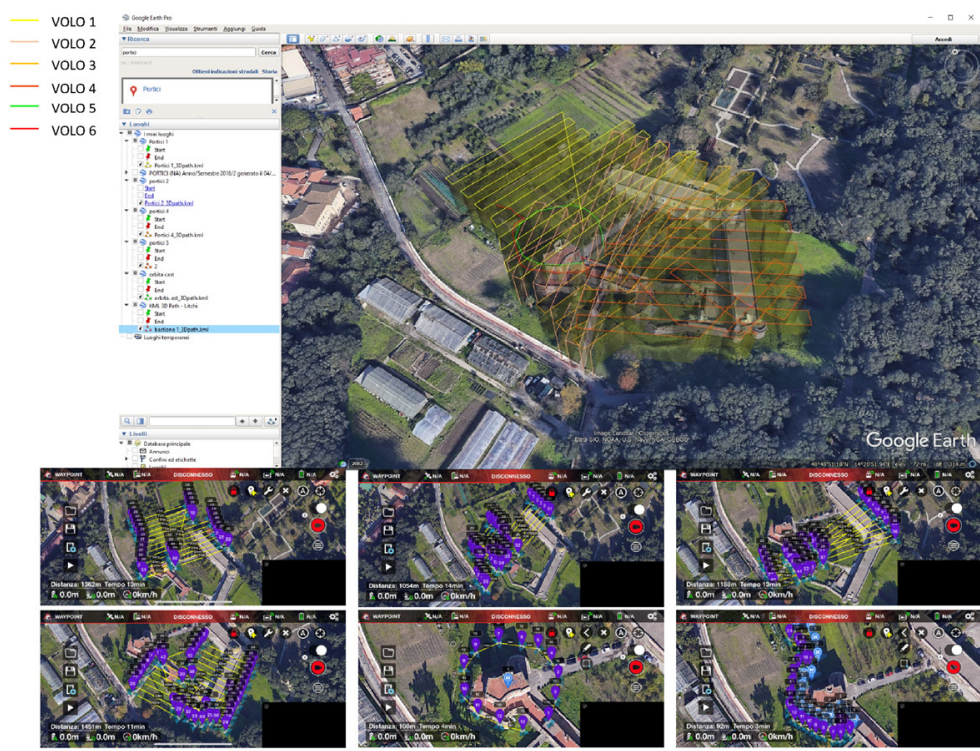


Fig. 7. Selection of technical documents for the graphic update from the photogrammetric model.

Fig. 8. The implementation of the model in the graphic engine: management of the geometric entities for the immersive output.

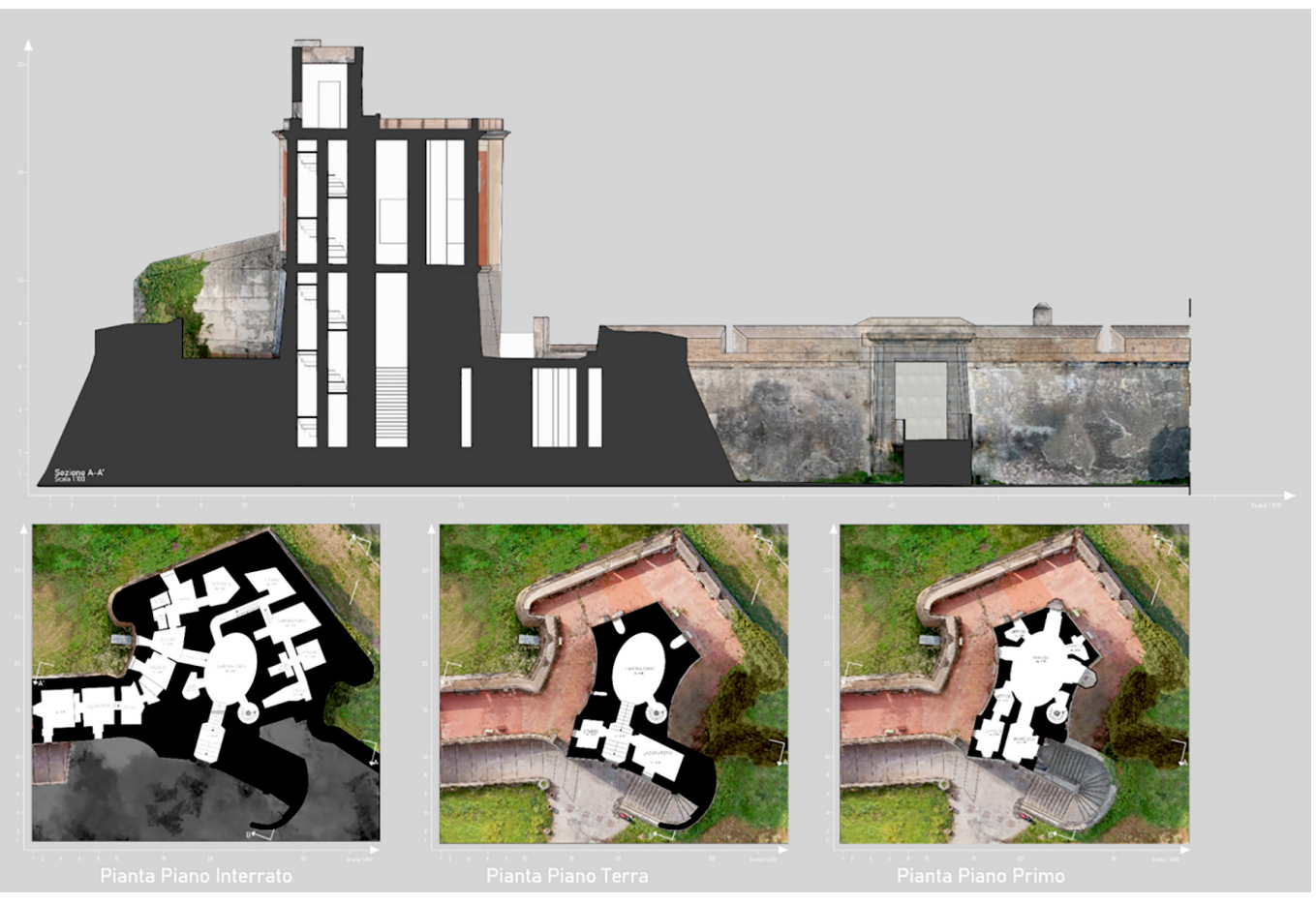

requires the use of a solid representation of the mesh type and, on the other hand, manifests the impossibility of integrating structured solid objects. This limit indeed becomes an opportunity in light of the ambition of interaction between the two moments imagined: the information system as such and the integrated virtual model when migrating to the application in virtual reality (VR).

Moreover, the mesh model allows the desired geometric consistency of the artefact, being able to obtain it through the aerial photogrammetry acquisition process itself, that allowed to draw up the cartographic update introduced and described previously. This is like saying that both the model implemented in the GIS platform and in Unreal Engine -the graphic engine used for this application- are arranged as a reliable digital reproduction of the Castle and the blockhouse at its boundary with a resolution widely adequate to simulate the object in the navigation during the virtual receptive accessibility and, for the interaction with expert users, to promptly recall the rigorous information of the formally reliable developed documents. (G.DA).

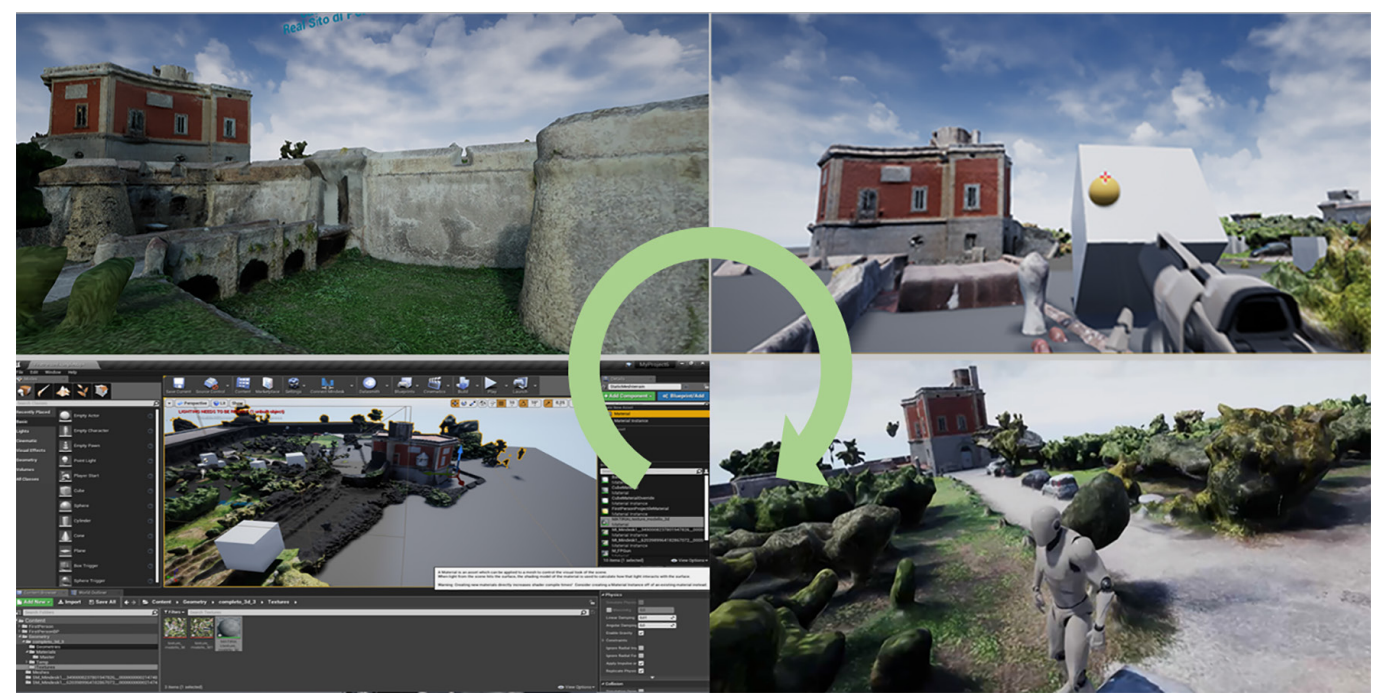




\section{Conclusions}

If it is easy to envisage that the practice to deal with imaginary scenarios, produced within platforms designed to create ideal interactive worlds for mere recreational and ludic purposes, has existed for more than half a century, the theme of the resort to modelling and digitizing of real contexts, that manifest themselves in their metric and coherent informative conditions within such procedures, is less immediate.

The need to integrate and distribute data related to a unique information and knowledge base, if linked to the knowledge of objects that are located in larger complex systems, manifests the need to produce graphic information through a process of rendering both at the territorial or urban scale and at the detailed scale. In particular, the development of advanced modelling tools and their interconnection with cross-platform graphic engines made available to a large and wide-ranging audience has also allowed the scientific community to test new ways of information arrangement. This arrangement is mainly considered as a viaticum capable of breaking down the distance between the moment of data collection and its sharing. (L.M.P.).
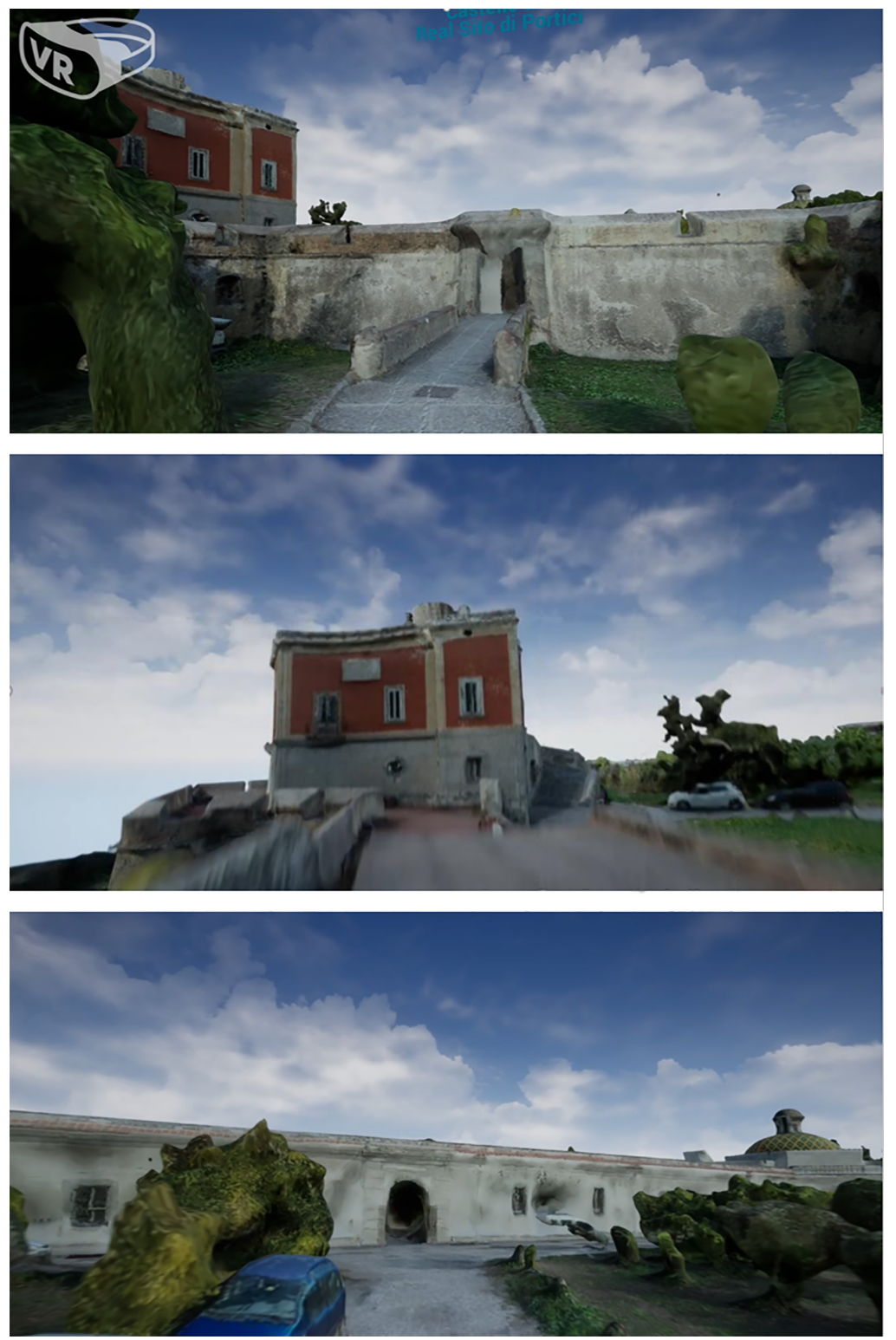


\section{Notes}

[I] The paper is edited by the two authors, specifically referring to the description and the coordination of the research activities. The singular effort are signed at sides of paragraphs' titulations.

[2] Fatta Francesca. Introduction. In Belardi 2019, p.16.

[3] The Royal Palace with parks and outbuildings was offered on sale in 187I and purchased by the Province of Naples which installed the Higher School of Agriculture and, in 1873, the Botanical Garden, reserving the areas of the Soprano Garden and of the adjacent Secret Garden for it. Currently the ownership of this portion is of the University of Naples Federico II with whose Technical Office the authors have been collaborating for several years. A mandatory dialogue has been engaged with the Soprintendenza Archeologia, Belle Arti e Paesaggio for the Municipality of Naples in the figure of arch. Serena Borea - area official at the Institution's Architectural Tutelage. The correspondence between the University and the Tutelage Institution, moreover, intervened in the light of the attention paid to an asset considered paradigmatic for the purposes of the MASBC Task Force (Analytical Methodologies ForThe Protection Of Cultural Heritage) promoted by the University of Naples Federico II, of which the authors are, respectively, member of the management committee and member.

[4] Giovanni Antonio Medrano, Antonio Carnevari and Luigi Vanvitelli mainly operated.

[5] Designed by the military engineer Michele Andrea under the direction of General Francesco Pignatelli, it is inspired by the Capua castle.

\section{References}

Centofanti Mario, Continenza Romolo, Ruggieri Gianfranco, Brusaporci Stefano, Trizio Ilaria (2008). II progetto del SIARCH - UNIVAQ, Sistema Informativo Architettonico. In: Mingucci Roberto, Centofanti Mario (ed.) Conservazione del Patrimonio Architettonico e Urbano. DisegnareCon, vol. I, n. 2.

Chías Navarro Pilar, Papa Lia Maria (2019). Territories, places and landscapes with figures. In: Chías Navarro Pilar, Papa Lia M. (a cura di). Drawing the territory and the landscape. DisegnareCon, vol. I 2, n.22, pp. I - 10.

D'Agostino Pierpaolo, Messina Barbara (2018). Digital Information Archives for an Integrated Documentation of Eremitical Settlements on Amalfi Coast. In: Marcos Carlos L. (ed.). Graphic Imprints. The Influence of Representation and Ideation Tools in Architecture. Cham: Springer International Publishing, pp. 88I-893.

Del Pezzo Nicola ( 1896). Siti Reali: il Palazzo Reale di Portici. In: Napoli Nobilissima, V, pp. I6 | - |67, I 83 - 88.

Fatta Francesca (2019). Prefazione. In: Belardi Paolo (a cura di). (2019). Riflessioni: l'arte del disegno/ il disegno dell'arte. Atti del $41^{\circ}$ Convegno Internazionale dei Docenti delle Discipline della Rappresentazione. Perugia 19-21 settempre 2019. Roma: Gangemi, p. $16-18$.

Nocerino Nicola (1787). La real villa di Portici. Napoli: Fratelli Raimondi, pp. 46-53.

Papa Lia Maria (2019). Considerations about Old Maps in the Digital Era. In: The Representation of Landscape, Environment and Territory. Diségno n. 5, pp. 91-102.

Smith Matthew, Walford Nigel Stephen, Jimenez-Bescos Carlos. (2019). Using 3D modelling and game engine technologies for interactive exploration of cultural heritage: An evaluation of four game engines in relation to roman archaeological heritage. In Digital Applications in archaeology and Cultural Heritage, 14, 2019, pp. I- 13.

\section{Authors}

Lia Maria Papa, Università degli Studi di Napoli “Federico II", Impapa@unina.it

Pierpaolo D’Agostino, Università degli Studi di Napoli "Federico Il", pierpaolo.dagostino@unina.it

To cite this article: Papa Lia Maria, D'Agostino Pierpaolo (2020). Un processo integrato di conoscenza e visualizzazione. II castello della Reggia di Portici/An integrated process for dissemination and visualization. The Castle in the Royal Site in Portici. In Arena A., Arena M., Brandolino R.G. Colistra D., Ginex G., Mediati D., Nucifora S., Raffa P. (a cura di). Connettere. Un disegno per annodare e tessere. Atti del $42^{\circ}$ Convegno Internazionale dei Docenti delle Discipline della Rappresentazione/Connecting. Drawing for weaving relationships. Proceedings of the 42th International Conference of Representation Disciplines Teachers. Milano: FrancoAngeli, pp. 25।5-2532 